\title{
The Baltic Historians of Pedagogy and the International Standing Conference for the History of Education
}

\author{
Iveta Ķestere \\ University of Latvia \\ Jūrmalas gatve 74/76, \\ Riga LV-1084, Latvia \\ E-mail: iveta.kestere@lu.Iv
}

More than two hundred historians of education from all over the world came together in Riga in August 2013 to attend the annual International Standing Conference for the History of Education (ISCHE). The coming of this conference to the Baltic countries and the journey of the Baltic historians of pedagogy to ISCHE took several decades.

ISCHE, which is the leading organization in the field of history of education in the world, was founded in 1979 in Leuven, Belgium. The initiators to establish the organization were scholars mainly from Belgium, the Federal Republic of Germany and the UK. The "socialist block" in this first meeting was represented by Poles and Hungarians. In the later years, the conference was organized annually in a different country sometimes gathering tens and even hundreds of participants (Lüth, n.d.). The first president of ISCHE was a fascinating personality, British lord and communist, one of the most outstanding historians of education in the $20^{\text {th }}$ century Brian Simon (1915-2002) (see McCulloch, 2011, pp. 41-54).

The aim of the ISCHE became fostering research and enhancing intellectual exchange and cooperation among historians of education around the globe (ISCHE, n.d.). Since 1995, the conference papers have been published regularly in the academic journal Paedagogica Historica (see Fuchs, 2014). In 2015, scholars from Latvia and Lithuania will be the journal's guest editors for the first time.

It is an interesting coincidence that historians of pedagogy of the Baltic countries also started their cooperation in the 1970s. University faculty met at conferences in Tallinn (1973, 1977, 1982, 1992), Vilnius (1980), Daugavpils (1975, 1978, 1981), Riga (1989, 1993) and Jaunpils (1991). The initiators of 
developing the research network among the Baltic countries were professors Lembit Andresen (Tallinn Pedagogical Institute), Aleksander Elango (19022004, Tartu University), Leonards Žukovs (Daugavpils Pedagogical Institute), Arvīds Salmiņš (1914-1984, Daugavpils Pedagogical Institute), Jonas Laužikas (1903-1980, Vilnius Pedagogical Institute), and Meile Lukšiene (1913-2009, Vilnius Pedagogical Institute) (Žukovs, 2009).

As the Baltic countries were part of the Soviet Union until 1991, from which the democratic world was separated by "the iron curtain", communication with the colleagues from the Western countries was next to impossible. Although the ISCHE conferences took place at the doorstep of the Soviet Union, namely in Warsaw (1980) and Budapest (1982), so far we know that the only Soviet scholar who participated in these was Kadriya Salimova (1924-2013). She, of course, came from Moscow and worked at the Academy of Pedagogical Sciences of the USSR (azeri.ru, 2008). It is also known that there was an initiative to organize ISCHE in Moscow in 1982, which was not carried out (Lüth, n.d.).

During the symposium that was held in May 1999 in Riga, the historians of pedagogy from Estonia, Latvia and Lithuania decided to establish the Baltic Association of Historians of Pedagogy (BAHP). BAHP was officially registered as a public organization with its branches in Lithuania and Estonia on July 4, 2000 in Riga (Žukovs, 2009, p. 7). Historians of pedagogy of the Baltic countries continued to meet regularly at conferences and prepared joint publications (see BAHP, 2004; Krūze et al., 2009; Kiestere \& Krūze, 2013). The study of the development of the science of pedagogy, history of the teaching profession, and history of educational institutions in the Baltic countries, as well as the facilitation of interest and understanding about the Baltic history in the context of European pedagogy became the aim of BAHP (n.d.). Prof. Leonards Žukovs was the standing president of BAHP for many years until 2010, when he passed this post to Prof. Aìda Krūze.

The collapse of the Soviet Union and the opening of "the iron curtain" created preconditions for the cooperation among the Baltic scholars and the historians of education abroad. ${ }^{1}$ However, arriving in the free world required overcoming several obstacles, which were mainly created by finances, inability to speak foreign languages, and the lack of well-rounded education. Therefore, the historians of pedagogy of the Baltic countries learned about ISCHE as late as in 2002, the year in which the conference took place at the University of Sorbonne in Paris.

Further on the activities of the historians of pedagogy of the Baltic countries after regaining the independence see Kestere, 2014. 


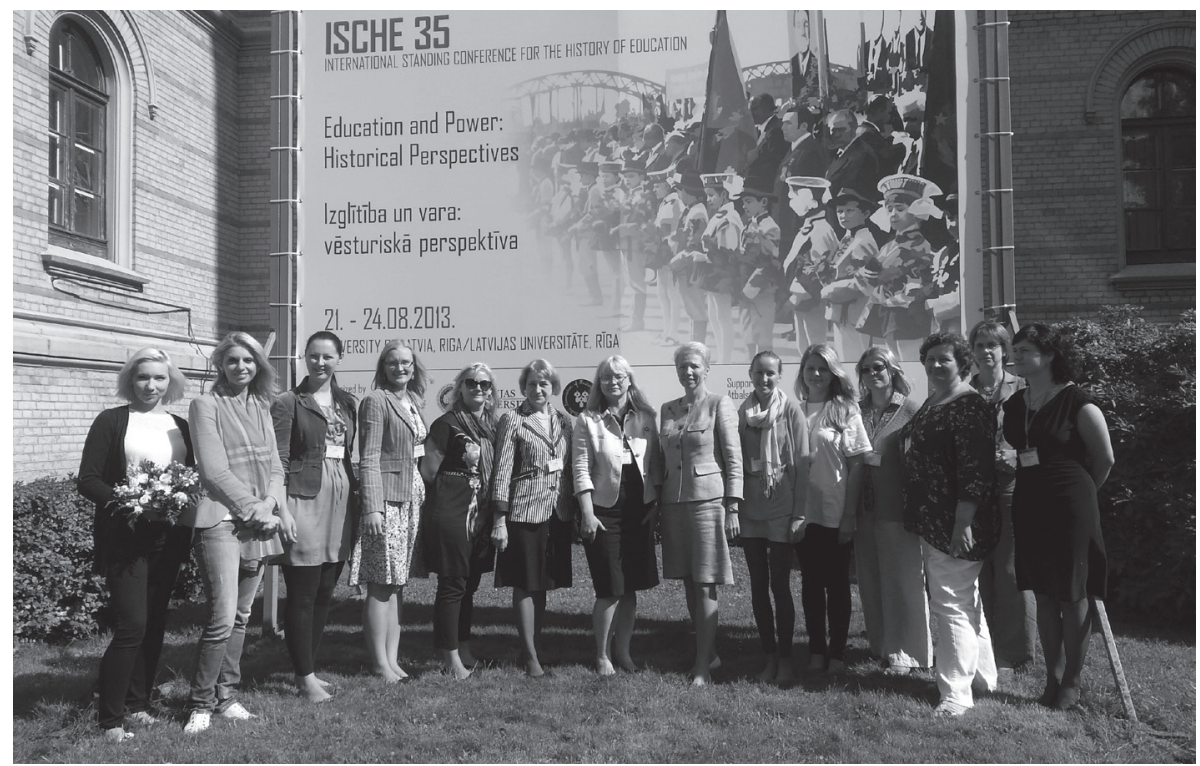

Fig. 1 The local Organizing Committee of ISCHE 35 at the conference poster. Riga,

University of Latvia, 24 August 2013.

Since then, Latvians who were later joined by Lithuanians and Estonians have regularly attended ISCHE. Thanks to ISCHE, the University of Latvia developed cooperation with outstanding historians of education: Vice-Rector Prof. Marc Depaepe from the University of Leuven (Belgium), Prof. Frank Simon from the University of Gent (Belgium), Prof. Maris Vinovskis from the University of Michigan (USA), and the University of Tallinn established cooperation with Prof. Gary McCulloch from the Institute of Education, University of London (UK).

Since 1979, ISCHE has been organized in Belgium, Poland, Hungary, France, Germany, Spain, Italy, Finland, Norway, Czechoslovakia, Switzerland, Portugal, Netherlands, Ireland, Australia, Brazil, Sweden, UK, USA and Mexico (twice in some of these countries)(ISCHE, 2014). In 2009, BAHP was invited to organize ISCHE 35 in 2013 at the University of Latvia in Riga.

As ISCHE 35 took place in the post-Soviet space, its theme was related to the past experience-education in the conditions of dictatorship. However, the final formulation of the topic, 'Education and Power: Historical Perspectives,' was wide enough for the scholars with different interests to find their place in the conference.

The total of 244 historians of education from 37 countries attended the ISCHE in Riga; they came from Argentina, Australia, Austria, Belgium, Canada, Chile, 
China, Columbia, Czech Republic, Estonia, Finland, France, Germany, Greece, Hungary, Israel, Italy, Japan, Korea, Latvia, Lithuania, Luxemburg, Mexico, New Zealand, Netherlands, Nigeria, Norway, Poland, Portugal, Russia, Slovenia, Spain, Sweden, Switzerland, Turkey, UK and USA. ISCHE 35, as usual, was academically oriented - its participants represented around 130 universities with 101 professors and 42 doctoral students among the participants. The work was organized in 60 sections. Some 200 papers which analyzed several theoretical problems connected with the relations of education and power in a historical perspective were presented in English, German, French and Spanish.

The papers were mainly devoted to agents and instruments of power in the field of education, especially turning their attention to the state that, certainly, owns the widest arsenal of tools for implementing the power. Education reforms introduced in different countries in different periods of time, revealing how any changes are implemented with the help of power, were the focus of the studies (e.g., Róuk, 2013, p. 137). The traditional agents of power in the field of education are teachers who are both the subject of power affected by the official authorities and the carriers of power who exert their influence on pupils. However, the opportunities provided by school and the power over the weakest are also used by others who, in their turn, may become the agents of power, for example medical doctors (e.g., Hofmann, 2012, p. 200). The reports on education and emotions in the classroom can also perform the role of power agents (e.g., Imlig \& Ruoss, 2013, p. 88; Landahl, 2013, p. 102).

Traditionally, power is treated as the domination of one agent of power over another (Giddens, 1997, p. 348; Bourdieu \& Passeron, 2011, p. 4), thus there is always the object in power relations that affects the subject. Manipulations of power with the subject are especially pronounced in totalitarian societies and a number of ISCHE 35 papers were devoted to this issue (e.g., Abens, 2013, p. 15; Krūze, 2013, pp. 100-101; Stonkuviene, 2013, p. 156). Several studies on the relations of particular personalities with power in all its forms of expression were also presented at the conference (e.g., Zigmunde, 2013, pp. 183-184).

The more aggressive the power and the more conscious it becomes, the wider and definite people's resistance gets. It is paradoxical that often the same agents and instruments used in implementation of power are also used in resistance to power. Such dual nature is characteristic of education. For instance, one of the most interesting papers at ISCHE 35 revealed how the Jews doomed to death in Kaunas ghetto learned the traditional culture (Frasier, 2013, p. 62). 
ISCHE 35 participants visited Jurmala and the Riga History and Navigation Museum where the Cross Passage of the Riga Cathedral had been the site of the first school in the Baltic countries-the Dom School, founded around 1211. The special event of the conference was the presentation of the book written by BAHP members, History of Pedagogy and Educational Sciences in the Baltic Countries from 1940 to 1990: an Overview. This book is the first attempt to tell in English the story based on historical sources about pedagogy and educational sciences during the Soviet dictatorship in the Baltic region.

After the conference, the ISCHE 35 organizers, among whom there were representatives from Universities of Latvia, Tallinn and Vilnius, received many thanks and the conference in Riga was appreciated also at this year's ISCHE 36, held in London. Seven historians of pedagogy from Latvia and Lithuania attended this conference. The plan envisages that the next ISCHEs will be organized in Istanbul (2015), Chicago (2016), and Buenos Aires (2017).

\section{References:}

Abens, A. (2013), 'Teacher education during and immediately after conflict - the case of Latvia from 1940-1956,' in Education and Power: Historical Perspectives. Abstracts. ISCHE 35, Riga: SIA Latgales druka, p. 15.

azeri.ru (2008), 'Salimova Kadriia-Ul'ker Ismail kyzy', 15 April 2008. Retrieved from http://www.azeri.ru/diaspora/persons/salimova_kadriya/ [accessed 10 Sep 2014]

BAHP (n.d.), Baltic Association of Historians of Pedagogy, [Home page] Retrieved from http://www.baltichistorians.lu.lv/index.php [accessed 9 Sep 2014]

- (2004), Pedagoǵijas vēstures pētniecība Baltijas valstīs: starptautiskas konferences zinātnisko rakstu krājums, 2004. gada 14.-15. maijs, Research into the History of Pedagogy in the Baltic States, Riga: Baltic Association of Educational Historians \& RaKa.

Bourdieu, P. \& Passeron, J.-C. (2011), Reproduction in Education, Society and Culture, $2^{\text {nd }}$ edition, Los Angeles, etc.: Sage.

Frasier, A. (2013), 'Schooling in the Kovno ghetto: cultural reproduction as a form of defiance,' in Education and Power: Historical Perspectives. Abstracts. ISCHE 35, Riga: SIA Latgales druka, p. 62.

Fuchs, E. (2014), 'The International Standing Conference for the History of Education and Paedagogica Historica: A historical view on publication strategies and international practices,' Paedagogica Historica, vol. 50, no. 6, pp. 737-755.

Giddens, A. (1977), Studies in Social and Political Theory, New York: Basic Books. 
Hofmann, M. (2013), 'Medical power and its influence on everyday school life in the late $19^{\text {th }}$ and early $20^{\text {th }}$ century in Switzerland,' in Education and Power: Historical Perspectives. Abstracts. ISCHE 35, Riga: SIA Latgales druka, p. 200.

Imlig, F. \& Ruoss, T. (2013), 'Evidence as source of power in school reforms,' in Education and Power: Historical Perspectives. Abstracts. ISCHE 35, Riga: SIA Latgales druka, p. 88.

ISCHE (n.d.), International Standing Conference for the History of Education, [Home page] Retrieved from http://www.ische.org/ [accessed 9 Sep 2014]

_ (2014), 'Past Conferences' in International Standing Conference for the History of Education, [Home page] Retrieved from http://www.ische.org/ische-conference/ past-conferences/ [accessed 9 Sep 2014]

Kestere, I. (2014), 'History of education and the struggle for intellectual liberation in post-Soviet Baltic space after the fall of the Berlin Wall,' Paedagogica Historica, vol. 50, no. 6, pp. 844-851.

Kestere, I. \& Krūze, A., eds. (2013), History of Pedagogy and Educational Sciences in the Baltic Countries from 1940 to 1990: an Overview, Riga: RaKa.

Krūze, A. (2013), 'Pedagogy research in Latvia under the Soviet rule (1945-1990),' in Education and Power: Historical Perspectives. Abstracts. ISCHE 35, Riga: SIA Latgales druka, pp. 100-101.

Krūze, A.; Kestere, I; Sirk, V. \& Tijūneliene, O., eds. (2009), History of Education and Pedagogical Thought in the Baltic Countries up to 1940: an Overview, Riga: RaKa.

Landahl, J. (2013), 'Emotions, power and the advent of mass schooling,' in Education and Power: Historical Perspectives. Abstracts. ISCHE 35, Riga: SIA Latgales druka, p. 102 .

Lüth, C. (n.d.), 'International Standing Conference for the History of Education (ISCHE), 1979-2000,' Institut Français de L'éducation, [Home page] Retrieved from http://www.inrp.fr/she/ [accessed 15 May 2014]

McCulloch, G. (2011), The Struggle for the History of Education, London \& New York: Routledge.

Róuk, V. (2013), 'Power and curriculum: Estonian case, 1987-1996, from the times of transition to adaptation,' in Education and Power: Historical Perspectives. Abstracts. ISCHE 35, Riga: SIA Latgales druka, p. 137.

Stonkuviene, I. (2013), 'What did it mean to be a pioneer?' in Education and Power: Historical Perspectives. Abstracts. ISCHE 35, Riga: SIA Latgales druka, p. 156.

Zigmunde, A. (2013), 'The psychoanalyst and pedagogue Ernst Schneider (1878-1957) in the controversial views of his contemporaries in Latvia,' in Education and Power: Historical Perspectives. Abstracts. ISCHE 35, Riga: SIA Latgales druka, pp. 183-184.

Žukovs, L. (2009), 'Introduction', in A. Krūze, I. K,estere, V. Sirk \& O. Tijūneliene (eds.) History of Education and Pedagogical Thought in the Baltic Countries up to 1940: an Overview, Riga: RaKa, pp. 6-8. 